\title{
Efektifitas Berbagai Metode Pembelajaran Untuk Partisipasi Aktif Mahasiswa dan Stimulasi Proses Clinical Reasoning
}

\section{Widyandana}

Bagian Pendidikan Kedokteran, Universitas Gadjah Mada Yogyakarta

\begin{abstract}
Background: Skills lab program can be conducted by several methods, such as training by mannequin, role play with peers, simulated patients, and training in community. Medical students are expected to play an active role in training and always practice their clinical reasoning skills. However, there are still many students not ready for implementing some medical procedure in their clerkship. Therefore, this study aimed to compare the level of active participation and the clinical reasoning process of students obtained in four learning methods in skills lab.

Methods: This study used a cross-sectional design with random survey questioner to 150 medical students in Medical Faculty of GMU $(n=150)$. This survey were expected to explore the impression of students to each learning method, particularly in the active participation in practice and the clinical reasoning process. The results were analyzed using descriptive quantitative method by comparing total score of each learning method.

Results and Discussion: The results showed that the learning method of medical skills in community is superior to 3 other methods, namely practice with mannequins, role play with peers, as well as simulated patients, both in promoting the active participation of students and stimulating the clinical reasoning skills $(p<0.05)$.

Conclussions: Medical skills training in community is more effective in promoting the active participation of students in practice and stimulating the clinical reasoning skills. However, it should considerate with compatibility of topic, students' readiness, and combined methods if needed.
\end{abstract}

Keywords: learning method, medical skills, mannequin, role play, peer, simulated patient, community, clinical reasoning, active participation.

\begin{abstract}
ABSTRAK
Latar Belakang: Skills lab dilaksanakan dengan berbagai metode, yaitu berlatih dengan manekin, roleplay dengan teman, pasien simulasi, maupun berlatih langsung di masyarakat. Melalui skills lab, mahasiswa kedokteran diharapkan dapat berperan aktif dalam berlatih keterampilan medis dan selalu mengasah kemampuan clinical reasoning. Namun, masih sering ditemui mahasiswa S1 kedokteran yang tidak siap melaksanakan suatu prosedur medis ketika memasuki pendidikan profesi. Oleh karena itu, penelitian ini bertujuan untuk membandingkan 4 metode pembelajaran yang paling efektif dalam melibatkan peran aktif mahasiswa dalam berlatih dan menstimulasi proses clinical reasoning mahasiswa.

Metode: Penelitian ini merupakan penelitian cross-sectional dengan random survey quesioner terhadap 150 mahasiswa Fakultas Kedokteran UGM (n:150). Survey dilakukan untuk mengeksplorasi kesan mahasiswa terhadap masingmasing metode pembelajaran, terutama partisipasi aktif dalam berlatih dan proses clinical reasoning. Hasil dianalisis secara kuantitatif deskriptif dengan membandingkan skor total masing-masing metode pembelajaran.

Hasil dan Pembahasan: Hasil penelitian menunjukkan bahwa metode pembelajaran keterampilan medis di masyarakat paling unggul dibandingkan 3 metode lainnya yaitu berlatih dengan manekin, roleplay dengan teman, maupun pasien simulasi, baik dalam memacu partisipasi aktif mahasiswa dalam berlatih maupun menstimulasi kemampuan clinical reasoning mahasiswa $(\mathrm{p}<0,05)$.

Kesimpulan: Latihan keterampilan medis dengan diterjunkan langsung ke masyarakat terbukti lebih efektif dalam memacu partisipasi aktif mahasiswa dalam berlatih dan menstimulasi kemampuan clinical reasoning. Namun
\end{abstract}

Korespondensi: widiyandana@yahoo.com 
demikian, tetap harus memperhitungkan kesesuaian topik latihan, kesiapan mahasiswa, dan kombinasi metoda jika diperlukan.

Kata Kunci: metode pembelajaran, keterampilan medis, manekin, roleplay, peer, pasien simulasi, masyarakat, clinical reasoning, partisipasi aktif.

\section{PENDAHULUAN}

Dewasa ini, inovasi dalam bidang pendidikan berkembang terus dengan sangat pesat di seluruh penjuru dunia. Demikian pula dengan bidang pendidikan kedokteran yang juga tidak lepas akan tuntutan tersebut. General Medical Council (GMC) tahun 2003 dalam Tomorrow's Doctor merekemondasikan bahwa selama proses belajar, kurikulum kedokteran harus memberikan pengetahuan yang esensial, keterampilan dan perilaku yang baik kepada mahasiswa sebelum mereka lulus. ${ }^{1}$ Sehingga dalam perkembangannya perlu terus dilakukan proses evaluasi dan inovasi metode pembelajaran di bidang pendidikan kedokteran demi terciptanya lulusan yang kompeten.

Pendidikan skills lab memegang peranan penting untuk melatih keterampilan medis mahasiswa kedokteran dalam memenuhi standar kompetensi mereka selama jenjang S1., ${ }^{2,3}$ Secara umum, pendidikan keterampilan medis diyakini dapat mempersiapkan mahasiswa S1 kedokteran untuk memasuki pendidikan profesi. ${ }^{2}$ Beberapa penelitian menunjukkan bahwa belajar keterampilan medis dapat meningkatkan motivasi belajar, tingkat kepercayaan diri, dan mempersiapkan mahasiswa kedokteran untuk memasuki pendidikan profesi. ${ }^{2,4,5}$ Selain itu, mengenai keefektifitasan pendidikan keterampilan medis terhadap tingkat keterampilan mahasiswa kedokteran menunjukkan bahwa mahasiswa yang dilatih di skills lab secara signifikan lebih terampil dibanding mahasiswa yang tidak mendapatkan latihan. ${ }^{6}$

Melalui pendidikan keterampilan skills lab, mahasiswa kedokteran diharapkan dapat berperan aktif dalam berlatih keterampilan medis dan selalu mengasah kemampuan clinical reasoning mereka. ${ }^{7,8}$ Dalam hal ini, partisipasi aktif dalam berlatih dan kemampuan clinical reasoning berperan penting dalam pencapaian kompetensi mahasiswa kedokteran. ${ }^{8,9}$ Terkait peningkatan kualitas latihan keterampilan medis, dengan adanya partisipasi aktif, mahasiswa dapat berproses untuk dapat lebih terampil melakukan berbagai keterampilan medis yang diajarkan. ${ }^{6}$ Sementara itu, clinical reasoning juga berperan penting dalam pencapaian kompetensi mahasiswa dan harus dilatih sejak dini, mengingat clinical reasoning terkait erat dengan proses yang panjang dan sangat menentukan bagi seorang dokter untuk mengambil keputusan dalam suatu tindakan medis. ${ }^{8}$ Sehingga kebutuhan akan suatu program keterampilan medis yang ideal bagi mahasiswa kedokteran, yang mampu meningkatkan partisipasi aktif dan kemampuan clinical reasoning mereka, menjadi penting.

Pelaksanaan pendidikan skills lab dilakukan dengan memberikan pelatihan keterampilan medis secara terstruktur dan terencana dengan baik, dengan menggunakan berbagai metode, yaitu berlatih dengan manekin, dengan teman/peer, pasien simulasi, maupun berlatih langsung di masyarakat. ${ }^{7}$ Suatu program keterampilan medis yang ideal untuk mahasiswa kedokteran memiliki kriteria antara lain; pelatihan keterampilan medis sebaiknya dimulai sejak dini, diawali dengan yang paling ringan berlanjut ke semakin kompleks, dan disesuaikan dengan tema blok sehingga membuat mahasiswa tertarik dan terfokus dalam belajar. ${ }^{10}$ Teori dan keterampilan yang diajarkan harus sesuai dengan realitas (contextual), sehingga mudah dimengerti oleh mahasiswa. Sementara tujuan pembelajaran juga harus jelas dan instruktur harus tahu kepentingan, cara melakukan, serta aplikasi dari keterampilan tersebut.

Sebagai salah satu institusi pendidikan kedokteran, Fakultas Kedokteran Universitas Gadjah Mada memberikan pendidikan keterampilan medis skills lab secara longitudinal dalam seluruh tahapan kurikulum pendidikan kedokteran S1. Masing-masing topik di Skills Lab FK UGM diberikan dalam beberapa tahapan, yaitu 
mahasiswa diajarkan keterampilan klinis oleh seorang intruktur yang ahli/telah terlatih dan menguasai keterampilan medis tertentu. Dalam latihan ini, mahasiswa dapat berlatih dengan manekin, roleplay dengan teman, pasien simulasi, dan di masyarakat. Masing-masing topik dilatihkan dengan metode yang berbeda-beda sesuai dengan karakteristik topik yang diajarkan. Setelah berlatih dengan instruktur, mahasiswa diberi kesempatan untuk berlatih secara mandiri untuk dapat menguasai topik keterampilan tersebut. ${ }^{11}$

Namun, permasalahan kemudian muncul ketika mahasiswa S1 kedokteran memasuki pendidikan profesi, yaitu ketika mereka bertemu dengan pasien yang sebenarnya untuk pertama kali. Permasalahan ini terjadi karena mahasiswa sering kali tidak siap melakukan suatu prosedur medis yang semula dilakukan dengan manekin di skills lab, kemudian harus diterapkan ke pasien yang sebenarnya. ${ }^{4}$ Dalam salah satu penelitian ditemukan bahwa masalah yang muncul ketika mahasiswa S1 kedokteran pertama kali memasuki pendidikan profesi berkaitan dengan masalah sosialisasi, beban kerja, dan perbedaan antara teori dengan praktik. ${ }^{12}$ Kecemasan juga merupakan permasalahan ketika mahasiswa pertama kali berhadapan dengan pasien di rumah sakit karena mereka takut melakukan kesalahan medis yang mungkin akan membahayakan pasien. ${ }^{13}$ Semua permasalahan tersebut tentu saja tidak terlepas dari peran penting pendidikan skills lab. Kesempatan untuk mahasiswa berlatih secara aktif dalam sesi latihan dan stimulasi untuk meningkatkan kemampuan clinical reasoning mahasiswa kemungkinan masih kurang, sehingga membuat mereka tidak mampu mencapai kompetensi yang dibutuhkan ketika memasuki pendidikan profesi. ${ }^{4,8}$

Melihat permasalahan di atas, penelitian ini bertujuan untuk membandingkan efektifitas empat metode latihan keterampilan medis di Skills Lab FK UGM, khususnya dalam hal kesempatan mahasiswa untuk berpartisipasi aktif dalam latihan dan stimulasi untuk meningkatkan kemampuan clinical reasoning mahasiswa. Dengan penelitian ini diharapkan dapat ditemukan metode pembelajaran yang paling efektif untuk menstimulasi mahasiswa dalam berpartisipasi aktif dalam berlatih keterampilan medis dan juga melatih kemampuan clinical reasoning.

\section{METODE}

Penelitian ini adalah penelitian cross sectional. Survey dilakukan di Fakultas Kedokteran Universitas Gadjah Mada, dengan melibatkan 150 orang mahasiswa $(n=150)$. Mahasiswa yang dilibatkan merupakan mahasiswa program reguler dengan kurikulum KBK dari angkatan 2006, 2007 dan 2008 yang sudah mendapatkan latihan di skills lab dengan empat metode pembelajaran (metode pembelajaran dengan manekin, roleplay dengan teman, pasien simulasi, dan berlatih langsung di masyarakat). Sampling dalam penelitian ini dilakukan secara acak. Survey ini menilai tingkat partisipasi aktif mahasiswa dalam berlatih keterampilan medis dan tingkat stimulasi untuk meningkatkan kemampuan clinical reasoning mahasiswa pada empat metode pembelajaran yang dilakukan di skills lab. Hasil penelitian kemudian dianalisa secara kuantitatif deskriptif dengan membandingkan skor total dan modus masing-masing variabel.

\section{HASIL DAN PEMBAHASAN}

Dalam penelitian ini terjangkau sebanyak 118 mahasiswa (tingkat respon=79\%). Selama penelitian berlangsung, ditemui beberapa kendala terkait waktu pelaksanaan penelitian. Penelitian dilakukan bersamaan ketika jadwal kegiatan mahasiswa cukup padat, yaitu mendekati ujian blok, sehingga penelitian ini mengalami kesulitan dalam merekrut responden penelitian. Keterbatasan waktu yang ada juga menjadi kendala dalam pelaksanaan penelitian ini.

Tingkat partisipasi aktif mahasiswa dalam berlatih keterampilan medis dengan 4 metode pembelajaran di skills lab

Hasil penelitian menunjukkan bahwa menurut mahasiswa metode pembelajaran yang paling memacu untuk berperan aktif dalam berlatih keterampilan medis adalah berlatih langsung di masyarakat. Metode pembelajaran berlatih langsung di masyarakat pada penelitian ini mendapat skor tertinggi dengan persentase skor 32,3\%. Hasil ini diikuti dengan metode berlatih dengan pasien simulasi $(31,6 \%)$, roleplay dengan teman $(22,6 \%)$ serta berlatih dengan manekin (13,6\%) (Gambar 1).

Metode pembelajaran berlatih langsung di masyarakat merupakan metode paling baik untuk meningkatkan 
partisipasi aktif mahasiswa karena metode ini memacu adanya rasa tanggung jawab lebih besar yang dirasakan mahasiswa ketika menghadapi pasien dibanding saat melakukan latihan dengan metode lain. Saat akan menghadapi pasien atau masyarakat di setting yang sebenarnya, mahasiswa terpacu untuk benar-benar berlatih sebelum sesi dan selama sesi. Sementara setelah sesi pun mereka akan termotivasi untuk mengulang kembali keterampilan tersebut jika dirasakan perlu.

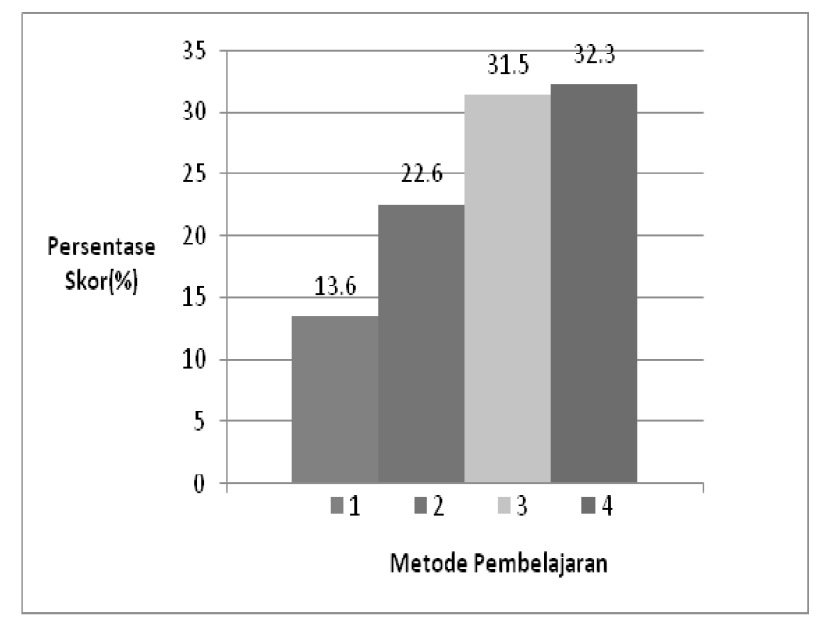

Keterangan: 1: Berlatih dengan manekin, 2: roleplay dengan teman, 3: berlatih dengan pasien simulasi, 4 : berlatih langsung di masyarakat

Gambar 1. Grafik komposisi persentase skor masingmasing metode pembelajaran di skills lab untuk tingkat partisipasi aktif mahasiswa

Dalam penelitian terdahulu, disebutkan bahwa sebaiknya dilakukan pendekatan jarak antara pendidikan berbasis laboratorium dengan pendidikan profesi yang ada di setting klinis, dengan cara membuat suatu simulasi yang mirip dengan keadaan yang sebenarnya ${ }^{14}$. Simulasi ini dapat memfasilitasi mahasiswa untuk dapat berlatih secara serius tetapi masih dalam setting yang aman. Demikian pula untuk membuat mahasiswa S1 lebih siap masuk pendidikan profesi di rumah sakit, sebaiknya mahasiswa dikenalkan dengan situasi klinis sedini mungkin ${ }^{15}$. Dengan memberikan paparan mahasiswa S1 terhadap situasi klinis dan pasien yang sebenarnya, maka akan memberikan pengalaman yang sangat berguna untuk menyiapkan mahasiswa memasuki profesi, memberikan gambaran mengenai profesi mereka sejak dini, dan akan memotivasi mahasiswa untuk belajar lebih giat untuk mencapai kompetensi mereka.

Tingkat stimulasi peningkatan kemampuan clinical reasoning ketika berlatih keterampilan medis dengan 4 metode pembelajaran di skills lab

Dalam hal tingkat stimulasi kemampuan clinical reasoning mahasiswa, hasil yang sama dengan hasil tingkat partisipasi aktif mahasiswa ketika berlatih keterampilan medis dengan 4 metode pembelajaran di skills lab ditemukan dalam penelitian ini. Menurut mahasiswa, metode pembelajaran yang paling memacu untuk meningkatkan kemampuan clinical reasoning dalam berlatih keterampilan medis adalah pembelajaran langsung di masyarakat. Hasil analisis dari yang terbaik, untuk tingkat stimulasi kemampuan clinical reasoning yaitu metode pembelajaran berlatih langsung di masyarakat dengan persentase skor $60,4 \%$, urutan diikuti dengan metode pasien simulasi $(23,3 \%)$, berlatih dengan manekin $(10,4 \%)$, kemudian roleplay dengan teman $(5,9 \%)$ (Gambar 2).

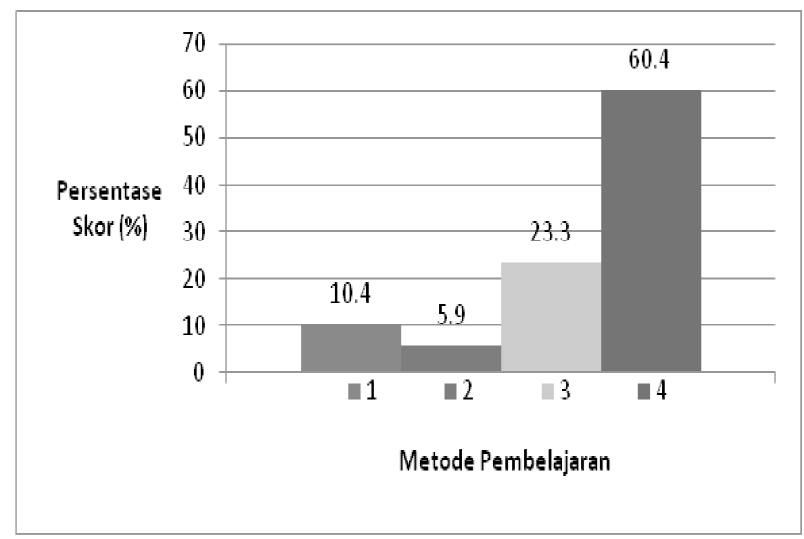

Keterangan: 1: Berlatih dengan manekin, 2: roleplay dengan teman, 3: berlatih dengan pasien simulasi, 4: berlatih langsung di masyarakat

Gambar 2. Grafik komposisi persentase skor masingmasing metode pembelajaran di skills lab untuk tingkat clinical reasoning mahasiswa 
Metode pembelajaran berlatih langsung di masyarakat dalam penelitian ini dirasa dapat memacu mahasiswa untuk dapat belajar clinical reasoning dengan lebih baik dibanding metode lainnya karena terkait adanya paparan lingkungan nyata. Paparan kasus-kasus nyata akan memacu mereka untuk berpikir lebih terstruktur, logis, dan benar-benar sesuai dengan kebutuhan mereka nanti saat berperan sebagai dokter..$^{15}$ Situasi ini berbeda dengan situasi di skills lab ketika berlatih dengan teman, manekin, maupun pasien simulasi yang cenderung lebih aman, terstruktur dan tersimulasi dengan baik. ${ }^{2,5}$ Situasi di skills lab ketika berlatih dengan teman, manekin, maupun pasien simulasi terkadang tidak memacu mahasiswa untuk berpikir lebih dalam untuk memecahkan permasalahan pasien. Hal ini yang selanjutnya menimbulkan masalah ketika mereka berhadapan dengan pasien yang sebenarnya di setting klinis. ${ }^{12}$

Perbandingan efektivitas 4 metode pembelajaran keterampilan medis di skills lab berdasar tingkat partisipasi aktif dan tingkat stimulasi kemampuan clinical reasoning mahasiswa

Secara keseluruhan dengan mempertimbangkan skor total, hasil penelitian ini menunjukkan bahwa terdapat perbedaan signifikan antara keempat metode pembelajaran di skills lab. Hasil uji statistik menggunakan uji Kruskal Wallis didapatkan hasil signifikansi $p=0,00 \quad(p<0,05)$, dengan metode pembelajaran langsung di masyarakat terbukti merupakan metode paling baik dalam pendidikan keterampilan medis. Selanjutnya hasil penelitian juga menunjukkan bahwa ada korelasi yang kuat dalam metode pembelajaran tersebut antara tingkat partisipasi aktif mahasiswa dengan pencapaian peningkatan clinical reasoning mahasiswa $(\mathrm{p}<0,05)$.

Hubungan yang kuat dalam tingkat keaktifan mahasiswa dengan kemampuan clinical reasoning menunjukkan bahwa dua hal tersebut saling terkait dan tidak dapat dipisahkan dalam pencapaian kompetensi mahasiswa sebelum memasuki pendidikan profesi. Hal tersebut sejalan dengan berbagai teori terkait proses pembelajaran yang menyatakan bahwa semakin mahasiswa aktif, maka proses pemahaman terhadap suatu prosedur medis atau suatu teori akan lebih baik dibandingkan mahasiswa yang cenderung pasif. ${ }^{16}$ Dengan memberikan kesempatan berlatih lebih awal dengan pasien di masyarakat tentu akan memberikan kesempatan yang lebih kepada mahasiswa dalam mengasah kemampuan klinis mereka, baik secara teori maupun praktik. ${ }^{15,16}$

Selanjutnya, meskipun dalam penelitian ini secara keseluruhan metode pembelajaran di masyarakat terbukti paling baik dalam pendidikan keterampilan medis, semua inovasi yang dilakukan tidak dapat lepas dari pertimbangan pendanaan yang ada dan manajemen yang akan melaksanakan program tersebut. ${ }^{17}$ Sehingga dalam hal ini perlu diselidiki kemungkinan inovasi tersebut dapat dilakukan secara ideal. Jika tidak mungkin dilaksanakan, maka akan lebih baik suatu inovasi dilakukan secara bertahap, dan direncanakan jauh-jauh hari agar dapat mencapai hasil yang optimal. Keterbatasan fasilitas, pendanaan, dan sumberdaya manusia selalu dihadapi oleh banyak institusi, maka hal ini merupakan suatu tantangan agar tetap dapat meningatkan kualitas metode pembelajaran keterampilan medis dengan segala keterbatasan yang ada. ${ }^{7,11}$ Perlu disadari bahwa inovasi dalam suatu program pendidikan harus dapat menguntungkan semua pihak, termasuk mahasiswa, institusi pendidikan, masyarakat, dan juga pasien yang terlibat. ${ }^{15}$

\section{KESIMPULAN}

Dari penelitian ini dapat disimpulkan bahwa mahasiswa menyadari pendidikan keterampilan medis dengan metode pembelajaran berlatih langsung di masyarakat dapat memicu keaktifan mahasiswa dalam berlatih dan meningkatkan kemampuan clinical reasoning mahasiswa. Hal tersebut diikuti dengan metode pembelajaran dengan pasien simulasi, roleplay dengan teman serta yang terakhir dengan manekin.

\section{SARAN}

Penelitian ini masih mempunyai banyak kekurangan, salah satunya yaitu hanya menjangkau sebagian kecil dari jumlah mahasiswa yang ada, sehingga untuk penelitian lebih lanjut sebaiknya dapat menjangkau jumlah mahasiswa yang lebih banyak. Selain itu, kekurangan juga terpadat pada pendapat instruktur maupun pasien simulasi yang terlibat yang belum dapat dieksplorasi terkait keterbatasan waktu yang ada. 
Sebaiknya hal ini perlu tetap dilaksanakan untuk memperkuat data yang ada dan mengurangi bias yang kemungkinan bisa ditimbulkan jika pengambilan data dilakukan hanya dari sisi persepsi mahasiswa. Penelitian lebih lanjut diharapkan dapat melengkapi kekurangankekurangan yang ada tersebut.

\section{DAFTAR PUSTAKA}

1. General Medical Council. Tomorrow's Doctors: recommendations on undergraduate medical education. London: General Medical Council; 2003.

2. Nielsen DG, Moercke AM, Hansen GW, Eika B. Skills training in laboratory and clerkship: connections, similarities, and differences. Med Educ Online [Internet]. 2003 [cited 2009 Apr 10];8:12. Available from http://www.med-ed-online.org.

3. Liddell MJ, Davidson SK, Taub H, Whitecross LE. Evaluation on procedural skills training in an undergraduate curriculum. Med Educ. 2002;36: 1035-41.

4. Smith B. From simulation to reality - breaking down the barriers. Clin Teach. 2006;3:112-7.

5. Van Dalen J, Flippo-Berger JF. Skills lab: centre for training of skills. Maastricht: Maastricht University Press; 1999.

6. Lynagh M, Burton R, Fisher RS. A systematic review of medical skills laboratory training: where to from here?. Med Educ. 2007; 41:879-87.

7. Leddingham IM, Harden RM. Twelve tips for setting up clinical skills training facility. Med Teach. 1998; 20(6):503-7.

8. Norman G. Research in clinical reasoning: past history and current trends. Med Educ. 2005; 39:418-27.
9. Lane C, Hood A, Rollnick S. Teaching motivational interviewing: using role play as effective as using simulatd patients. Med Educ. 2008; 42:637-44.

10. Remmen R, Scherpbier A, van der Vleuten C, Denekens J, Derese A, Hermann I, et al. Effectivenes of basic clinical skills training programes: a crosssectional comparison of four medical schools. Med Educ. 2001;35:121-8.

11. Claramita M, Widyandana. The skills laboratory. Yogyakarta: Faculty of Medicine Gadjah Mada University Press; 2008.

12. Prince KJAH, Boshuizen HPA, van der Vleuten C, Scherpbier AJJA. Students opinions about their preparation for clinical practice. Med Educ. 2005;39:704-12.

13. Sarikaya O, Civaner M, Kalaca S. The anxieties of medical students related to clinical training. Int J Clin Pract. 2006; 60(11):1414-8.

14. Kneebone RL, Scott W, Darzi A, Horrocks M. Simulation and clinical practice: strengthening the relationship. Med Educ. 2004;38:1095-102.

15. Dornan T, Littlewood S, Margolis SA, Scherpbier A, Spencer J, Ypinazar V. A BEME systematic review: how can experience in clinical and community settings contribute to early medical education?. Med Teach. 2006;28(1):3-18.

16. Custers EJFM, Regehr G, Mcculloch W, Peniston C, Reznick R. The effects of modelling on learning a simple surgical procedure: see one, do one or see many, do one?. Adv Health Sci Educ. 1999; 4:123. 43.

17. Stark P, Fortune F. Teaching clinical skills in developing countries: are clinical skills centres the answer? Educ Health. 2003;16(3):298-306. 